\author{
Marek Bartoń \\ Zespół Szkół Zawodowych nr 1 \\ im. Gen. Jerzego Ziętka, Katowice
}

\title{
Przedsiębiorczość jako przedmiot matury 2008
}

Postęp cywilizacyjno-technologiczny oraz transformacja polityczno-gospodarcza są sumą zmian i przeobrażeń systemu gospodarczego, który decyduje ostatecznie o tempie i poziomie rozwoju gospodarczego danego kraju. Dokonujące się przemiany dotyczą również konieczności dostosowania systemu oświaty w Polsce.

Nawiązując do myśli przewodniej konferencji „Przedsiębiorczość a współczesne wyzwania cywilizacyjne"1, autor ma zamiar udowodnić tezę, iż nauczany przedmiot: podstawy przedsiębiorczości powinien mieć właściwe miejsce $\mathrm{w}$ strukturze systemu oświaty w naszym kraju.

Istniejąca podstawa programowa dla przedmiotu podstawy przedsiębiorczości dla szkolnictwa ponadgimnazjalnego stanowi, iż „,...)W liceum ogólnokształcącym, liceum profilowanym i technikum uczniowie kształcą swoje umiejętności w celu wykorzystania zdobytej wiedzy we współczesnym świecie. Szczególnie istotnym zadaniem jest odpowiednie przygotowanie uczniów do podjęcia pracy"2.

Nauczyciele tworzą uczniom warunki do nabywania następujących umiejętności:

1. planowania, organizowania i oceniania własnej nauki, przyjmowania za nią odpowiedzialności,

2. skutecznego porozumiewania się w różnych sytuacjach, prezentacji własnego punktu widzenia i uwzględniania poglądów innych ludzi, poprawnego posługiwania się językiem ojczystym, przygotowywania do publicznych wystąpień,

3. efektywnego współdziałania w zespole, budowania więzi międzyludzkich, podejmowania indywidualnych i grupowych decyzji, skutecznego działania na gruncie zachowania obowiązujących norm,

4. rozwiązywania problemów w twórczy sposób,

5. poszukiwania, porządkowania i wykorzystywania informacji z różnych źródeł, efektywnego posługiwania się technologiami informacyjnymi i komunikacyjnymi,

6. odnoszenia do praktyki zdobytej wiedzy oraz tworzenia potrzebnych doświadczeń i nawyków,

7. rozwijania sprawności umysłowych oraz osobistych zainteresowań,

8. przyswajania sobie metod i technik negocjacyjnego rozwiązywania konfliktów i problemów społecznych.

\footnotetext{
${ }^{1}$ Pierwsza Ogólnopolska Metodyczna Konferencja Naukowa „Przedsiębiorczość a współczesne wyzwania cywilizacyjne" odbyła się w Krakowie, dn. 27-28 września 2004 r. (organizator: Zakład Przedsiębiorczości i Gospodarki Przestrzennej Instytutu Geografii Akademii Pedagogicznej w Krakowie oraz Krajowe Centrum Edukacji Nauczycieli); jednym z wiodących tematów w dyskusji podczas obrad konferencji była problematyka matury z podstaw przedsiębiorczości (przyp. red.).

${ }^{2}$ http://www. menis. gov. pl/prawo/rozp_155/zal_4.htm
} 
W oparciu o ogólną podstawę programową ${ }^{3}$ ministerstwo zatwierdziło i wpisało do wykazu programów szkolnych program kształcenia ogólnego dla przedmiotu podstawy przedsiębiorczości w wymiarze 2 godziny w cyklu nauczania (dla liceum, technikum i liceum profilowanego $)^{4}$. Cele edukacyjne przedmiotu podstawy przedsiębiorczości ${ }^{5}$ traktowane są jako przedmiot ogólnokształcący i mają za zadanie:

1. Przygotowanie do aktywnego i świadomego uczestnictwa w życiu gospodarczym.

2. Kształcenie postawy rzetelnej pracy i przedsiębiorczości.

3. Kształtowanie umiejętności pracy w zespole i skutecznego komunikowania się.

4. Kształtowanie umiejętności aktywnego poszukiwania pracy i świadomego jej wyboru.

5. Poznanie mechanizmów funkcjonowania gospodarki rynkowej.

6. Rozwijanie zainteresowania podejmowaniem i prowadzeniem działalności gospodarczej.

7. Poznanie podstawowych zasad podejmowania i prowadzenia działalności gospodarczej w różnych formach.

8. Poznanie roli państwa i prawa w gospodarce rynkowej.

9. Poznanie zasad funkcjonowania gospodarki europejskiej i światowej.

Zgodnie z celami edukacyjnymi autorzy podręczników do przedmiotu podstawy przedsiębiorczości zawarli treści, w których około $75-80 \%$ to wiadomości z zakresu podstaw ekonomii (Belka, 2002; Stańda, Wierzbowska,2004; Korba, Smutek, 2003). Pozostała treść odpowiada zagadnieniom ściśle związanych $\mathrm{z}$ interdyscyplinarnym charakterem ekonomii jako nauki społecznej. Od początku reformy oświaty w Polsce, autor stara się o uznanie przedmiotu podstawy przedsiębiorczości (oczywiście $\mathrm{w}$ zakresie rozszerzonym, np. pod nazwą ,ekonomia”) jako przedmiotu maturalnego.

Historia zabiegów o uznanie przedmiotu traktującego wiedzę ekonomiczną we właściwy jej sposób sięga początków reformy szkolnictwa ponadgimnazjalnego ${ }^{6}$. Podjęte starania $\mathrm{w}$ zakresie uznania przedmiotu $\mathrm{z}$ dziedziny nauk społecznych (podstawy przedsiębiorczości) sięgają czasów pierwszych prac nad podstawami standardów maturalnych dla większości przedmiotów.

Do dziś funkcjonują np.: wiedza o tańcu, filozofia ${ }^{7}$, itp. W Centralnej Komisji Egzaminacyjnej pod kierownictwem Pani Jadwigi Uss powołany zespół opracował podstawy standardów do przeprowadzenia egzaminu z przedmiotu ,podstawy ekonomii”(wcześniejszy odpowiednik podstaw przedsiębiorczości w zakresie rozszerzonym). Niestety, stwierdzono wówczas, iż nie ma podstaw MENiS z tego przedmiotu i prace nad egzaminem maturalnym wstrzymano.

Podjęte starania o uznanie nowego przedmiotu podstawy przedsiębiorczości jako przedmiotu maturalnego w nowej strukturze oświaty nie znajdują należnego zainteresowania. Obecnie żadna $\mathrm{z}$ instytucji odpowiedzialnych za egzamin maturalny ${ }^{8}$ nie jest zainteresowana pracami nad zmianą tej sytuacji.

Autora dziwi takie podejście do sprawy, gdyż system zreformowanego szkolnictwa w Polsce oparty jest o doświadczenia krajów europejskich. W świetle tych doświadczeń

\footnotetext{
${ }^{3}$ Podstawa programowa MENiS z dnia 26. 02. 2002 (Na podstawie art. 22 ust. 2 pkt. 2 lit. a i b ustawy z dnia 7 września 1991 r. o systemie oświaty (Dz. U. z 1996 r. Nr 67, poz. 329 i Nr 106, poz. 496, z 1997 r. Nr 28, poz. 153 i Nr 141, poz. 943, z 1998 r. Nr 117, poz. 759 i Nr 162, poz. 1126, z 2000 r. $\mathrm{Nr} 12$, poz. 136 , $\mathrm{Nr} 19$, poz. $239, \mathrm{Nr} 48$, poz. 550, $\mathrm{Nr} 104$, poz. 1104 , $\mathrm{Nr} 120$, poz. 1268 i Nr 122, poz. 1320 oraz z 2001 r. Nr 111, poz. 1194 i Nr 144, poz. 1615)

${ }^{4}$ Zob., np. DKOS-4015-81/02; DKOS-4015-191/02; DKOS-5002-9/03; DKOS-4015-177/02

${ }^{5}$ Tamże

${ }^{6}$ Wówczas szkolnictwa ponadpodstawowego.

${ }^{7}$ Filozofia jako przedmiot został wycofany decyzją Ministra Pani K. Łybackiej, jednakże ma powrócić w 2008 roku.

${ }^{8}$ Pisma i zapytania skierowano m.in. do CKE Warszawa, MENiS, OKE Jaworzno, Kuratorium Oświaty w Katowicach itd.
} 
szkolnictwo europejskie traktuje wiedzę ekonomiczno-społeczną z odpowiednim tej nauce szacunkiem, uznając ekonomię jako przedmiot maturalny".

Systemy oświaty krajów Wspólnoty Europejskiej dopuszczają możliwość zdawania matury z przedmiotu „ekonomia”. (Kunz, Kozler, 2002).

Dlaczego więc w Polsce, gdzie podstawy przedsiębiorczości nauczane są właściwie od III klasy gimnazjum (ścieżka z przedmiotu „Wiedza o społeczeństwie), nie istnieje możliwość uznania tego przedmiotu jako egzaminu maturalnego i będącego zarazem egzaminem wstępnym na bardzo popularne kierunki ekonomiczne? Obecnie, uczniowie ubiegający się o przyjęcie na kierunki ekonomiczne pozbawieni są możliwości wykazania się swoimi zainteresowaniami i wiedzą z zakresu ekonomii, a uczelnie ustalają warunki rekrutacji biorąc pod uwagę wyniki egzaminu maturalnego z przedmiotów, których zakres tematyczny odbiega w sposób znaczący od kierunku studiów. Między uczelniami jest bardzo duże zróżnicowanie w tym zakresie, co utrudnia kandydatom podjęcie decyzji odnośnie do wyboru przedmiotów egzaminu maturalnego.

Dla przykładu, oczywiste jest, że potencjalny student Politechniki powinien wykazać się znajomością matematyki, fizyki, chemii etc. Przedmioty te może zdawać na egzaminie maturalnym. W przypadku kandydata na studenta kierunków ekonomicznych, uczelnie wobec braku uznania rangi przedmiotu podstaw przedsiębiorczości, żądają wiedzy z zakresu różnych przedmiotów np. geografii, historii, wiedzy o społeczeństwie, matematyki itp.

Przed współczesnym wyzwaniem cywilizacyjnym stoją zatem działania na rzecz przedsiębiorczości, który jako przedmiot powinien znaleźć właściwą rangę i prestiż poprzez umożliwienie sprawdzenia wiadomości na jednym z najważniejszych egzaminów w życiu młodego człowieka. Autor proponuje uruchomienie procedur zmierzających do wprowadzenia podstaw przedsiębiorczości w zakresie rozszerzonym o nazwie „podstawy ekonomii” jako egzaminu maturalnego w roku 2008.

\section{LITERATURA}

Kunz V., Kozler J., 2002, Maturujeme z ekonomie. 4. Vydani. Mirago Ostrava. Belka M. (red.), 2002, Ekonomia stosowana. FMP, Warszawa

Stańda B., Wierzbowska B., 2004, Bądź przedsiębiorczy. PWN, Warszawa.

Korba J., Smutek Z., 2003, Podstawy przedsiębiorczości. WP,,Operon”, Gdynia.

\footnotetext{
${ }^{9}$ www.menis.gov.pl (Szkoły Europejskie): „W szkole średniej od pierwszej klasy zajęcia z przedmiotów artystycznych i zajęcia $\mathrm{z}$ wychowania fizycznego prowadzone są w drugim języku nauczania. Począwszy od klasy trzeciej w tym samym języku wykładana jest historia i geografia, a od klasy następnej również ekonomia i inne przedmioty humanistyczne wybrane przez ucznia. Do samej matury uczniowie uczą się w języku ojczystym matematyki, biologii, chemii i fizyki i w tymże języku zdają maturę $\mathrm{z}$ tych przedmiotów. Matura $\mathrm{z}$ przedmiotów nauczanych $\mathrm{w}$ drugim języku nauczania zdawana jest $w$ danym języku".
} 